\title{
Philosophia fundamentalis Friedricha Adolfa Trendelenburga
}

\author{
Wojciech HANUSZKIEWICZ*
}

\begin{abstract}
Friedrich Adolf Trendelenburg's philosopbia fundamentalis: Friedrich Adolf Trendelenburg (1802-1872) is an author who connects two periods. On the one hand, he attended the lectures of one of the first followers of Immanuel Kant - Karl Leonhard Reinhold, he knew personally and was influenced by Georg Wilhelm Friedrich Hegel and Friedrich Wilhelm Joseph von Schelling. On the other hand, Trendelenburg has educated a very large group of important figures within the German philosophy of the late nineteenth and early twentieth century (e.g., Wilhelm Dilthey, Franz Brentano and Hermann Cohen). His main work, Logische Untersucbungen (Logical investigations), was to see its release in three editions during his life. In the second edition Trendelenburg adds an introductory chapter, entitled Logik und Metaphysik als grundlegende Wissenschaft [Logic and metaphysics as a basic science]. It presents the idea of philosophy as a science and, like a lens, focuses on the most influential metaphilosophical solutions of the second half of the nineteenth century. The article in its first part presents the academic biography of Trendelenburg, while in the second it discusses the most important meta-philosophical problems raised in Logische Untersuchungen.
\end{abstract}

\section{KEYWORDS}

Friedrich Adolf Trendelenburg; Logische Untersuchungen (Logical investigations); metaphilosophy; philosophy as a science; logic; metaphysics

* Dr, adiunkt w Katedrze Filozofii Społecznej Instytutu Filozofii i Socjologii Uniwersytetu Pedagogicznego w Krakowie. E-mail: wojciechhan@wp.pl. 
Friedrich Adolf Trendelenburg ${ }^{1}$ jest dzisiaj filozofem prawie zupełnie zapomnianym. Nie zmienia to jednak faktu, iż był on w swoim czasie bardzo ważną postacią niemieckiego życia naukowego, zaś jego podstawowe dzieło filozoficzne, tj. Logische Untersuchungen [Badania logiczne], miało bardzo duży wpływ na rozwój filozofii niemieckiej drugiej połowy XIX wieku (Trendelenburg, 1840). Szczególnie ważna okazała się wyłożona w tym dziele sama koncepcja filozofii. Najpełniej zaprezentowana została ona w rozdziale zatytułowanym Logik und Metaphysik als grundlegende Wissenschaft [Logika i metafizyka jako nauka podstawowa] ${ }^{2}$. Rozdział ten otwiera wspomniane Logische Untersuchungen, począwszy od drugiego wydania tej pracy ${ }^{3}$. Dzieło to stanowi jedno z najważniejszych ogniw pośrednich wiążących ze sobą wielkie systemy idealizmu niemieckiego autorstwa Johanna Gottlieba Fichtego, Friedricha Wilhelma Josepha von Schellinga i Georga Wilhelma Friedricha Hegla oraz sytuującą się względem nich w opozycji filozofię Johanna Friedricha Herbarta z różnymi nurtami filozoficznymi powstałymi na przełomie XIX i XX wiekú. Można tutaj wymienić chociażby szkołę Franza Brentana, ruch neokantowski czy hermeneutyczną filozofia życia Wilhelma Diltheya. Trendelenburg w pełni słusznie uchodzić może również za prekursora fermentu intelektualnego, jaki doprowadził ostatecznie do sformułowania przez Gottloba Fregego zasad współczesnej logiki matematycznej ${ }^{5}$.

Nie sposób wszystkich tych wątków, nawet tylko szkicowo, przedstawić $\mathrm{w}$ jednym artykule, wszystkie one - powyżej zostało wspomnianych tylko kilka najważniejszych - nadal czekają na osobną monografię historycznofilozoficzną. Plan proponowanej poniżej prezentacji musi tedy zostać zakrojony

${ }^{1}$ Trendelenburg podpisywał się bądź dwoma imionami (Friedrich Adolf), bądź, co zdarzało się częściej, tylko jednym (Adolf).

${ }^{2}$ Publikowany w niniejszym tomie, zob. s 167-174.

${ }^{3}$ Praca ta miała za życia Trendelenburga trzy wydania — odpowiednio w latach: 1840, 1862 i 1870 . W trzecim wydaniu rozdział prezentujący koncepcję filozofii nie uległ żadnym zmianom. W wydaniu pierwszym natomiast nie jest on w ogóle zamieszczony. W dalszych analizach korzystam z wydania trzeciego (por. Trendelenburg, 1870a; Trendelenburg, 1870b).

${ }^{4}$ Filozofię Trendelenburga określa się najczęściej mianem późnego idealizmu bądź spirytualizmu. Drugim kluczowym filozofem tamtej epoki łączonym zazwyczaj z tym nurtem jest Rudolf Hermann Lotze (por. w tej kwestii: Baiser, 2013).

${ }^{5}$ Związki koncepcji Trendelenburga $\mathrm{z}$ analizami późniejszych autorów (w tym między innymi Brentana, Diltheya i Fregego) zostały omówione przez kilku autorów w pracy zbiorowej poświęconej oddziaływaniu Trendelenburga na filozofię niemiecką (Hartung \& Köhnke, 2006). Współczesne zainteresowanie Trendelenburgiem rozpoczęło się od zwrócenia uwagi przez Klausa Christiana Köhnkego na szczególne znaczenie Trendelenburga dla rozwoju neokantyzmu (Köhnke, 1986). Wychodząc od ustaleń Köhnkego, w Polsce pisano na ten temat kilkakrotnie (Kazimierczak, 1999; Noras, 2012). Na szczególną uwagę zasługuje ponadto praca Krzysztofa Rottera analizująca prace Trendelenburga w kontekście wspomnianych już przemian, jakie zaczęły zachodzić w obrębie logiki od lat czterdziestych XIX wieku, które doprowadziły do sformułowania na nowo podstaw tej dyscypliny (Rotter, 1999). 
o wiele skromniej. Jej celem będzie jedynie uchwycenie specyfiki metafilozofii Trendelenburga, czyli jego zapatrywań na samo pojęcie filozofii. W pierwszej części niniejszego artykułu (I) omówiona zostanie sylwetka intelektualna autora Logische Untersucbungen, część druga (II) naświetlać natomiast będzie przewodnią ideę metafilozoficzną wyłożoną przez niego we wspomnianym pierwszym rozdziale jego głównej pracy.

\section{I}

Trendelenburg urodził się w 1802 roku w Eutin ${ }^{6}$. Swoją edukację uniwersytecką rozpoczął w roku 1822 na uniwersytecie w Kiel. Jego pierwszymi nauczycielami byli tam Karl Leonhard Reinhold - jeden z pierwszych zwolenników i propagatorów filozofii transcendentalnej Kanta w Niemczech — oraz Johann Erich von Berger, urodzony w Danii uczeń Fichtego. W roku 1823 Trendelenburg przeniósł się na rok do Lipska, poświęcając się tam przede wszystkim studiom z zakresu filologii klasycznej, ostatnie zaś dwa lata nauki spędził w Berlinie. Słuchał tam między innymi wykładów Georga Wilhelma Friedricha Hegla (z filozofii dziejów), Friedricha Daniela Ernsta Schleiermachera (z estetyki) oraz Henricha Steffensa (z filozofii przyrody). Po pierwszym semestrze, bardzo zniechęcony do filozofii Heglowskiej i jej metody, porzucił wykłady samego Hegla, uczęszczał wszelako jeszcze na wykłady z Heglowskiej logiki, które prowadził Leopold von Henning. W Berlinie Trendelenburg poświęcił się jednak głównie badaniom nad filozofią starożytną, w tej dziedzinie pozostawał pod przemożnym wpływem Augusta Boeckha, choć uczęszczał również między innymi na zajęcia Immanuela Bekkera. Efektem zainteresowań Trendelenburga starożytnością była dysertacja Platonis de ideis et numeris doctrina ex Aristotele illustrata (Trendelenburg, 1826), która od razu przyniosła mu uznanie.

Po ukończeniu studiów Trendelenburg był nauczycielem domowym. W okresie tym nie porzucił jednak pracy naukowej, przygotowując opatrzoną krytycznym komentarzem edycję De anima Arystotelesa. Praca ta - w części krytycznej napisana po łacinie - ukazała się w roku 1833 (por. Trendelenburg, $1833 \mathrm{a})^{7}$. W tym samym roku Trendelenburg powołany został na stanowisko profesora filozofii praktycznej i pedagogiki na uniwersytecie berlińskim. W latach czterdziestych XIX wieku wykładał tam między innymi razem z Schellingiem i był świadkiem burzliwych polityczno-filozoficznych debat toczonych w środowisku młodoheglistów. Do grona jego studentów należał w tamtym

${ }^{6}$ Szczegółową biografię Trendelenburga można znaleźć w pracy Ernsta Bratuschecka (Bratuscheck, 1873).

${ }^{7} \mathrm{~W}$ tym samym roku ukazuje się również króciutki wykład o kategoriach Arystotelesa. Por. Trendelenburg, 1833b. Na temat badań Trendelenburga nad psychologią Arystotelesa i ich wpływie na poszukiwania badawcze Brentana por. Fugali, 2009. 
okresie Søren Kierkegaard. Z uczelnią w Berlinie Trendelenburg związany był do końca życia, pełniąc w niej rozmaite funkcje, w tym również rektorskie.

Badania Trendelenburga koncentrowały się wokół kilku zagadnień. Był przede wszystkim wytrawnym znawcą filozofii Arystotelesa i w dużym stopniu przyczynit się do renesansu arystotelizmu w Niemczech ${ }^{8}$. Jego rozprawy poświęcone Arystotelesowskiej nauce o kategoriach i jej recepcji (Trendelenburg, 1846) do dziś uznawane są za podstawowe prace poświęcone tej problematyce 9 Z racji zajmowanego stanowiska Trendelenburg podejmował również zagadnienia filozofii praktycznej oraz pedagogiki. Najważniejszą jego publikacją w tym zakresie była rozprawa poświęcona etyce i prawu naturalnemu (Trendelenburg, 1860 ${ }^{10}$. Badania Trendelenburga nad pedagogiką nigdy nie zostały opubliowane, niemniej w spuściźnie rękopiśmiennej znajduje się dość dużo materiałów dotyczących tej tematyki ${ }^{11}$.

Trendelenburg był jednakże dla swoich współczesnych przede wszystkim jednym z najważniejszych krytyków Hegla ${ }^{12}$. Logische Untersuchungen, pozostając główną pracą systematyczną Trendelenburga, zawierają zresztą nie tylko ostrą krytykę Heglowskiej filozofii, ostrze polemicznych wywodów skierowane jest w nich również przeciw Herbartowi i Kantowi. Przedstawiona w drugim wydaniu tej pracy krytyka Kanta wywołała trwający kilka lat spór z Kuno Fischerem (Fischer, 1865; Trendelenburg, 1869; Fischer, 1870). Ze sporu tego - dotyczącego ontycznego statusu apriorycznych form naoczności — Trendelenburg

${ }^{8} \mathrm{Z}$ tej perspektywy prezentuje filozofię Trendelenburga Peter Petersen, którego praca (wraz z wymienioną w przyp. 6 publikacją Bratuschecka) stanowi jeden z podstawowych punktów odniesienia dla badań nad filozofią Trendelenburga (Petersen, 1913). Bardzo wielu uczniów autora Logische Untersuchungen prowadziło mniej lub bardziej szeroko zakrojone badania nad Arystotelesem. Do grona tego należą między innymi: Hermann Bonitz, wspomniany już Brentano, Rudolf Eucken (pierwszy w historii filozof, który otrzymał literacką Nagrodę Nobla), Karl Prantl czy Gustav Teichmüller.

${ }^{9}$ Praca ta ukazała się w ramach trzytomowych Historische Beiträge zur Philosophie (por. Trendelenburg, 1846-1867). Na temat jej znaczenia i oddziaływania por. Fugali, 2012.

${ }^{10}$ Zagadnieniom szeroko rozumianej filozofii praktycznej Trendelenburg poświęcał wiele uwagi. Niektóre prace odnosiły się również do tematów zajmujących wówczas opinię publiczną (Trendelenburg, 1870c).

${ }^{11}$ Rękopis liczy 771 kart. Por. w tej kwestii: Langewand, 2002. Pewne wątki pedagogiczne można odnaleźć w dwutomowych Kleinere Scbriften (Trendelenburg, 1871). Warto może dodać, że wśród uczniów Trendelenburga są również pedagodzy: Friedrich Paulsen (filozof neokantowski i pedagog) oraz Otto Willmann (jeden z klasyków dydaktyki).

${ }^{12} \mathrm{~W}$ tym kontekście Trendelenburg — tak jak szereg innych autorów - pozostawał pod wpływem Schellinga. Zaprezentowana przez Trendelenburga krytyka Hegla (Trendelenburg, 1843; Trendelenburg, 1870a: 36-129) wpłynęła między innymi na Kierkegaarda. Kwestie te ujęte zostały w syntetyczny sposób w klasycznej już rozprawie Karla Löwitha, por. Löwith, 2001: 145-153. Warto może w tym miejscu zaznaczyć, iż przedstawiona przez Trendelenburga krytyka dialektyki Heglowskiej miała silne oddziaływanie nie tylko w dziejach filozofii niemieckiej XIX wieku. Jej wpływ jest również widoczny w koncepcji dialektyki negatywnej Teodora W. Adorna (Adorno, 1986: 214-215, przyp.). 
ostatecznie się wycofał, ponieważ ataki Fischera zaczęły być coraz bardziej natarczywe. Kontrowersja ta wywarła szczególny wpływ na rozwój neokantyzmu ${ }^{13}$.

Filozofia Trendelenburga bardzo szybko odeszła jednakże w zapomnienie. Myśliciel zmarł 24 stycznia 1872 roku. Po jego śmierci prace jego autorstwa nie były już wznawiane ${ }^{14}$. Przewodnia metafilozoficzna koncepcja Trendelenburga - postulująca ujęcie filozofii jako nauki, które to ujęcie wymykałoby się schematom pozytywistycznym i zarazem stanowiłoby podstawę naukowo uprawianej metafizyki wyznaczającej wraz z logiką naczelne pojęcia i zasady nauki — była w równej mierze dla następnych pokoleń niezbędna, jak i, co rychło wyszło na jaw, niemal niemożliwa do zrealizowania.

Podstawową koncepcją, jaką w powyższym kontekście wprowadza Trendelenburg w swych analizach metafilozoficznych, rozpoczynających drugie i trzecie wydanie jego Logische Untersuchungen (Trendelenburg, 1870a: 4-14), jest uznanie istnienia nauk szczegółowych za warunek pojawienia się filozofii jako odrębnej dziedziny wiedzy. Konstatacja ta tylko w pierwszym momencie może wydawać się niezgodna z powszechnie przyjętą koncepcją rozwoju filozofii, z której dopiero wyłoniły się na przestrzeni wieków poszczególne nauki. Trendelenburg nie przeczy bynajmniej temu, iż poszczególne dziedziny badań powstały w wyniku podziału pierwotnie niezróżnicowanego, i tym samym całościowego, poznania rzeczywistości. Autor Logische Untersuchungen podkreśla wszelako, iż filozofia, traktowana jako jedna z wielu możliwych dziedzin wiedzy, mogła

${ }^{13}$ Cały spór wybuchł w wyniku krytyki, jaką Fischer skierował pod adresem tezy sformułowanej przez Trendelenburga po raz pierwszy w drugim wydaniu Logische Untersuchungen, stwierdzającej, iż argumentacja Kanta dopuszcza obiektywistyczne ujęcie czystych form naoczności (przestrzeni i czasu), gdyż myślicielowi z Królewca nie udało się uzasadnić twierdzenia, iż mogą one posiadać jedynie subiektywny charakter (Trendelenburg, 1870a: 156-170). Wśród uczniów Trendelenburga do nurtu neokantowskiego zalicza się zazwyczaj Hermanna Cohena, Jürgena Bonę Meyera, wspomnianego już Paulsena, Aloisa Riehla oraz Hansa Vaihingera. Cohen napisał nawet obszerny artykuł poświęcony debacie Fischera i Trendelenburga (Cohen, 1871). Poza pracami wymienionymi w przyp. 5 warto również wspomnieć poświęcone tym kwestiom analizy Krystyny Święcickiej (Święcicka, 1976; Święcicka, 1980).

${ }^{14}$ Wyjątek stanowi tu właściwie tylko edycja Arystotelesowskiego traktatu $O$ duszy, wznowiona w 1877 roku, oraz podręczniki: Elementa logices Aristotelicae oraz Erläuterungen zu den Elementen der aristotelischen Logik. Ten pierwszy do roku 1892 miał dziewięć wydań (Trendelenburg, 1836). Również ostatnie wydanie komentarza do logiki Arystotelesa po niemiecku ukazało się już po śmierci Trendelenburga, mianowicie w roku 1876. Praca ta (Trendelenburg, 1842) miała jednak w sumie trzy wydania i nigdy nie była tak popularna jak podręcznik napisany po łacinie. W okresie późniejszym ukazał się właściwie tylko jeden niedrukowany wcześniej krótki tekst Trendelenburga pt. Zur Geschichte des Wortes Person, wydany z teki pośmiertnej przez Rudolfa Euckena (Trendelenburg, 1908). 
ujawnić się w całej swojej specyfice tylko dzięki konfrontacji z już istniejącymi naukami szczegółowymi, jakie się z niej wyłoniły w wyniku jej historycznego rozwoju. Filozofia - rozpatrywana jako pierwotna, początkowo niezróżnicowana na odrębne dziedziny całość wiedzy — stanowi tym samym rację istnienia poszczególnych nauk, niemniej dopiero wyodrębnienie się tychże nauk pozwala uchwycić specyfikę samej refleksji filozoficznej. Fakt istnienia nauk szczegółowych stanowi tym samym rację poznawczą, dzięki której zgłębiona mogła zostać specyfika myślenia filozoficznego ${ }^{15}$. Tego typu zależność można, nota bene, zaobserwować już u Arystotelesa. Specyfikę badań filozoficznych, dla których ukut on miano filozofii pierwszej, autor ten ukazał poprzez przeciwstawienie ich innym badaniom naukowym, nazywanym przez niego filozofią drugą.

W ten sposób uchwycony nieodzowny i nieredukowalny związek zachodzący pomiędzy filozofią a naukami szczegółowymi pozwala dopiero samą filozofię ujmować jako naukę ${ }^{16}$. Trendelenburg związek ten opisuje, posługując się trzema, wzajemnie się uzupełniającymi opozycjami: dystrybutywnej opozycji szczegółowość-ogólność, kolektywnej (mereologicznej) opozycji część-całość oraz modalnej opozycji przypadkowość-konieczność. W przeciwieństwie do filozofii badającej najbardziej ogólne pojęcia i zasady pozostałe nauki prowadzą szczegółowe badania nad wybranym fragmentem (częścią, wycinkiem) rzeczywistości, ich punkt wyjścia pozostaje więc z natury rzeczy czymś przypadkowym. Filozofia natomiast może zostać zadaniem autora Logische Untersuchungen określona mianem nauki o idei wyznaczającej ogólny porządek tego, co szczegółowe, oraz wiążącej poszczególne fragmenty (części) wiedzy w jedną całość, co pozwala początkowo przypadkowemu poznaniu empirycznemu nadać walor konieczności.

Tak rozumiane ogólność, całościowość i konieczność nie są przy tym, podkreśla Trendelenburg, narzucane naukom szczegółowym z zewnątrz. One same, twierdzi niemiecki filozof, zaczynają się ich domagać przynajmniej w tym zakresie, w jakim odkrywają w swoich obszarach jakieś zasady bądź podstawowe pojęcia, które $\mathrm{z}$ jednej strony okazują się dla nich niezbędne, z drugiej zaś nie moga zostać z ich własnej perspektywy wyjaśnione i uchwycone w ich pełnej ogólności. Wszystkie tego typu spory o podstawy jakiejś określonej nauki, na przykład o podstawy matematyki, okazują się zdaniem Trendelenburga sporami, które w jakiejś przynajmniej mierze dotyczą wszystkich nauk, gdyż poszczególne dziedziny wiedzy są ze sobą wzajemnie powiązane. W związku z tym wszelkie takie kontrowersje okazują się w ostatecznym rozrachunku sporami metafizycznymi bądź — jeśli ująć całą rzecz nieco ostrożniej — sporami naprowadzającymi na metafizyczne pytania o byt, to znaczy o to, co naprawdę istnieje.

${ }^{15}$ Innymi słowy naukę ujmuje Trendelenburg jako kulturowy fakt, który jako taki stanowi przedmiot badań filozofii (Trendelenburg, 1870a: 130-131; szerzej na ten temat: Orth, 2001).

${ }^{16}$ Wpływ analiz Trendelenburga na rozwijaną w Niemczech na przełomie XIX i XX wieku koncepcję filozofii jako nauki (przede wszystkim, ale nie tylko, dotyczy to nurtu neokantowskiego) został przeanalizowany szerzej w pracy: Hanuszkiewicz, 2011: 61-84. 
Ogólność, całościowość i konieczność bytu nie są, trzeba to podkreślić, ujmowane przez autora Logische Untersuchungen przedmiotowo. Byt nie jest przedmiotem, o którym cechy te można byłoby orzec. Jest natomiast zasadą, która potrafi określić, to, co naprawdę (ogólnie, całościowo, koniecznie) jest. W tym kontekście byt jest tożsamy z ogólną zasadą ruchu, z której wypływa cały porządek rzeczy. Ruch pozostaje jednakże zarazem konkretnym fenomenem, w którym sama zasada ruchu może dopiero znaleźć swój wyraz. Każdy fenomen, jaki ma zostać pojęciowo uchwycony przez myślenie, musi być rozumiany bowiem w swych dwóch różnych aspektach. Fenomen zawsze pozostaje przeciwstawną względem myślenia rzeczą, to znaczy czymś, czego z samego myślenia nie da się $\mathrm{w}$ żaden sposób wyprowadzić. Wszelako w tym aspekcie, w jakim wyraża on ogólną zasadę porządku, nie jest już li tylko czymś dającym się uchwycić w samej zmysłowej intuicji. Jeśli chcemy ująć w jakiś sposób zasadę, to możemy to zrobić wyłącznie w myśleniu (por. Trendelenburg, 1870b: $178-179)^{17}$.

Jeżeli byt będziemy rozumieli zatem jako zasadę, to wszelka metafizyka jako nauka o bycie - musi zostać powiązana od razu z logiką jako nauką o poprawnej metodzie myślenia. Zasady — będące zawsze określonymi twierdzeniami ujętymi w zdania - można sformułować tylko posługując się właściwą metodą. W ostatecznym rozrachunku myślenie i byt nie stanowią zatem dwóch całkowicie przeciwstawnych względem siebie elementów (obiektów), lecz tworzą relacyjną strukturę. Niezależnie od niej ani bytu, ani myślenia nie można byłoby w ogóle uchwycić. Trendelenburg w swoich wywodach nawiązuje do dialektyki Platona stwierdzającej nieodzowną korelację, jaka musi zachodzić między myśleniem i bytem. Myślenie jest zawsze myśleniem o czymś, wszelkie zaś coś jest zawsze obiektem uchwyconym w porządku myślenia. Korelację tę można uznać za sformułowaną avant la lettre zasadę intencjonalności, którą $\mathrm{w}$ różnych postaciach można odnaleźć u wielu autorów pozostających pod mniej lub bardziej bezpośrednim wpływem Trendelenburga, w tym przede wszystkim u samego Brentana, który walnie przyczynił się do przywrócenia należytego znaczenia tej średniowiecznej w swej proweniencji zasadzie ${ }^{18}$.

${ }^{17} \mathrm{~W}$ tej samej perspektywie można ujmować także przedstawioną przez Trendelenburga krytykę filozofii Hegla. O ile myślenie, jak chciał tego Hegel, znajduje się w ruchu, to fakt ten może zostać uchwycony w myśleniu tylko dlatego, iż sam ruch jest fenomenem, różnym od samego myślenia, do którego myślenie musi się już odnosić. Nie zmienia to jednakże faktu, iż ów ruch pozostaje zarazem zasadą porządkującą strukturę zarówno myślenia, jak i rzeczywistości. Jak zauważa Adorno wykorzystujący ten właśnie wątek analiz Trendelenburga, sytuacja powyższa powoduje, iż wszelki myślowy porządek powiązany jest z czymś, co z racji swej niewyprowadzanej z samego myślenia empiryczności temu porząadkowi się wymyka i co uruchamia ruch dialektyki negatywnej. (Adorno odsyła w tym kontekście - por. powyżej przyp. 12 - do fragmentu: Trendelenburg, 1870a: 91-92).

${ }^{18} \mathrm{Na}$ temat zagadnienia intencjonalności i jego metafizycznych implikacji u Trendelenburga, Brentana i Lotzego por. szerzej: Orth, 1998. 
W ujęciu Trendelenburga wszelki metafizyczny spór o podstawy nauk, jak i metafizyczno-logiczna koncepcja odniesienia intencjonalnego (by posłużyć się terminem Brentana) tworzą dwa nierozerwalne aspekty ambitnie zarysowanego programu badań filozoficznych określonego mianem philosopbia fundamentalis (Trendelenburg, 1870a: 14). Badania te z jednej strony miały pozostać gruntownie metafizyczne, z drugiej strony zaś miały spełniać wszystkie logiczno-metodologiczne wymogi nauk szczegółowych. Tak ambitnie zarysowany program następnym pokoleniom przestał wydawać się możliwy do zrealizowania. Dla jednych był zbyt metafizyczny, dla drugich zbyt naukowy. Pierwsze ślady nieuchronnego rozejścia się myślenia naukowego z myśleniem metafizycznym można zresztą zaobserwować już u samego Trendelenburga. Otóż jeśli przyjmiemy, iż refleksja filozoficzna rodzi się w momencie, gdy poznanie naukowe, roszcząc sobie pretensje do bycia poznaniem koniecznym, ogólnym i całościowym, odkryje swój różnorako uwarunkowany, ograniczony i nieusuwalnie cząstkowy charakter, to musimy zadać pytanie, w jaki sposób możemy w ogóle uzyskać tę ogólną i całościową perspektywę, która miałaby wykraczać poza obszar nauk szczegółowych. Trendelenburg wyjaśnia, iż ideę całości, bez której nie byłoby ani nauki, ani filozofii, uzyskujemy „pchani skłonnością umysłu” (Zug des Geistes) (Trendelenburg, 1870b: 452). Idea ta - tożsama $\mathrm{z}$ ideą świata - z konieczności przekracza wszelkie doświadczenie, którego poszczególnymi aspektami zajmują się nauki. Jeśli wszelako ideę całości uznamy za konstytutywną dla samej idei nauki, to za Trendelenburgiem będziemy musieli stwierdzić, iż „idea nauki sięga tu dalej niż jej faktyczna realizacja” (Trendelenburg, 1870b: 452).

Rozwiązanie takie kryje w sobie przy tym jedną istotną trudność. Jeżeli bowiem przyjmiemy, iż poszczególne nauki z konieczności dysponują skończoną, cząstkową perspektywą, to pojawia się pytanie, czy całościowa perspektywa filozoficzna może uchodzić za dostępną przy pomocy środków poznawczych, jakie ma do dyspozycji badanie naukowe. Problem powyższy Trendelenburg dostrzegał bardzo wyraźnie. Zastrzegał w tym kontekście, iż filozoficzne ujęcie całości świata nie jest nigdy ujęciem czysto dyskursywnym (pojęciowym), lecz zawsze wiąże się z jakąś obrazową intuicją. Owa intuicja (Anschauung) powinna tworzyć przy tym z dyskursywnym poznaniem naukowym, jak i z różnymi formami działania jedną spójną strukturę (Trendelenburg, 1870b: 454-456). Niemniej sama intuicja pozostaje czymś zgoła odmiennym i niesprowadzalnym do poznania naukowego. Ma to również i ten skutek, iż uprawianiu nauki mogą towarzyszyć odmienne wizje świata i odmienne światopoglądy ${ }^{19}$. Trendelenburg wymienia dwa ich podstawowe typy, tj. światopogląd mechaniczny (fizyczny) oraz organiczny (Trendelenburg, 1970b: 496-510). Pierwszy z nich za podstawową strukturę i siłę świata uznaje związek przyczynowy, drugi natomiast tego typu strukturę czy też siłę upatruje w teleologii. Autor Logische Untersuchungen

\footnotetext{
${ }^{19}$ Trendelenburg posługuje się tu dwoma rzeczownikami: Weltansicht oraz Weltanschauung.
} 
opowiada się zdecydowanie za tym drugim, zaznacza jednakże, iż przy pomocy samych badań naukowych nie jesteśmy w stanie definitywnie rozstrzygnąć zagadnień światopoglądowych.

Poszukiwana przez filozofię jedność może zatem być jedynie jednością osiąganą środkami logiki i poznania naukowego. Kwestie światopoglądowe pozostają właściwie poza jej zasięgiem, choć zarazem nie sposób ich wyeliminować (por. Köhnke, 1986: 57). Dla następnych pokoleń rozdźwięk między filozofią uprawianą jako filozoficzna refleksja nad naukami szczegółowymi, a problemami światopoglądu, do których zaczęto sprowadzać wszelką problematykę metafizyczną, okazał się niemożliwy do pokonania. Musimy radzić sobie z nim $\mathrm{w}$ jakiś sposób do dnia dzisiejszego. Stanowi on jeden z najistotniejszych problemów filozoficznych, jakie odziedziczyliśmy w dużej mierze właśnie po Trendelenburgu i jego uczniach — z Brentanem, Cohenem i - last but not least Diltheyem na czele ${ }^{20}$.

\section{BIBLIOGRAFIA}

Teksty Trendelenburga:

Trendelenburg, F. A. (1826). Platonis de ideis et numeris doctrina ex Aristotele illustrata. Lipsiae: Vogel.

Trendelenburg, F. A. (1833a). Aristotelis De anima libri tres. Ad interpretum graecorum auctoritatem et codicum fidem recognovit commentariis illustravit Fridericus Adolphus Trendelenburg. Jena: Walz. (Editio altera emendata et aucta 1877 Berolini: Weber. $=1957$ Graz: Akademische Druck- u. Verlagsanstalt).

Trendelenburg, F. A. (1833b). De Aristotelis Categoriis. (Muneris professorii prolusio). Berolino: Petsch.

Trendelenburg, F. A. (1836). Elementa logices Aristotelicae. In usum scholarum ex Aristotele excerpsit, convertit, illustravit Fridericus Adolphus Trendelenburg. Berolino: Bethge. (Editio tertia recognita et aucta [Elementa logices Aristotelae...] 1845 Berolino: Bethge. Editio nona 1892 Berolino: Weber).

Trendelenburg, F. A. (1840). Logische Untersuchungen. 2 Bände. Berlin: Bethge (2. erg. Auflage 1862 Leipzig: Hirzel. 3. verm. Auflage 1870 Leipzig: Hirzel. = 1964 Hildesheim: Olms).

Trendelenburg, F. A. (1842). Erläuterungen zu den Elementen der aristotelischen Logik, zunächst für den Unterricht in Gymnasien. Berlin: Bethge (2. verm. Aufl. 1861 Berlin: Weber. 3. Aufl 1876).

Trendelenburg, F. A. (1843). Die logische Frage in Hegel's System: Zwei Streitschriften. Leipzig: Brockhaus.

Trendelenburg, F. A. (1846-1867). Historische Beiträge zur Pbilosophie. 1. Band (1846). Geschicbte der Kategorienlebre. Zwei Abhandlungen. 2. Band (1855). Vermiscbte Abhandlungen. 3. Band (1867). Vermischte Abhandlungen. Berlin: Bethge.

Trendelenburg, F. A. (1849). Über den letzten Unterschied der philosophischen Systeme (s. 241-262). W: Abbandlungen der König. Preuss. Akadademie der Wissenschaften zu Berlin. Berlin: Verlag der König. Preuss. Akademie der Wissenschaften (Samodzielne wydanie:

${ }^{20} \mathrm{O}$ związkach łączących teorię światopoglądów Diltheya z koncepcjami Trendelenburga por. Wach, 1926. Rzecz jasna Trendelenburg nie był dla Diltheya jedynym źródłem inspiracji. 
1949 Neu hg. sowie mit einer Einleitung u. erl. Anmerkungen versehen von Hermann Glockner. Stuttgart: Frommann.).

Trendelenburg, F. A. (1860). Naturrecht auf dem Grunde der Etbik. Leipzig: Hirzel. (2. ausgeführtere Auflage 1868. = 1969 Aalen: Scientia)

Trendelenburg, F. A. (1869). Kuno Fischer und sein Kant: Eine Entgegnung. Leipzig: Hirzel.

Trendelenburg, F. A. (1870a). Logische Untersuchungen. 1. Band. 3. verm. Auflage. Leipzig: Hirzel.

Trendelenburg, F. A. (1870b). Logische Untersucbungen. 2. Band. 3. verm. Auflage. Leipzig: Hirzel.

Trendelenburg, F. A. (1870c). Lücken im Völkerrecht: Betrachtungen und Vorscbläge aus dem Jabre. Leipzig: Hirzel.

Trendelenburg, F. A. (1871). Kleine Schriften. 2 Bände. Leipzig: Hirzel.

Trendelenburg, F. A. (1908). Zur Geschichte des Wortes Person. Kant-Studien, 13, 1-17.

Trendelenburg, F. A. (1969). Elemente der aristotelischen Logik: griechisch und deutsch. Zusammengestellt, übersetzt und kommentiert von Adolf Trendelenburg. Bearb. und neu hrsg. von Rainer Beer (Wydanie to zawiera prace: Elementa logices Aristotelae oraz Erläuterungen zu den Elementen der aristotelischen Logik).

Pozostałe cytowane prace:

Adorno, T. W. (1986). Dialektyka negatywna. (Przeł. K. Krzemieniowa przy współpracy S. Krzemienia-Ojaka). Warszawa: Państwowe Wydawnictwo Naukowe.

Baiser, F. C. (2013). Late German idealism. Trendelenburg and Lotze. Oxford: Oxford University Press.

Bratuscheck, E. (1873). Adolf Trendelenburg. Berlin: Henschel.

Cohen, H. (1871). Zur Controverse zwischen Trendelenburg und Kuno Fischer. Zeitscbrift für Völkerpsychologie und Sprachwissenschaft, 7, 249-296. [Przedruk w: Görland, A. \& Cassirer, E. (Red.). (1928). Schriften zur Philosopbie und Zeitgeschichte (s. 229-275). Bd. 1. Berlin: Akademie-Verlag].

Fischer, K. (1865). System der Logik und Metaphysik oder Wissenschaftslebre. Heidelberg: Bassermann.

Fischer, K. (1870). Anti-Trendelenburg. Eine Gegenschrift. Jena: Dabis.

Fugali, E. (2009). Toward the rebirth of Aristotelian psychology: Trendelenburg and Brentano (s. 179-202). W: S. Heinämaa \& M. Reuter (Red.). Psychology and philosophy: Inquiries into the soul from late scholasticism to contemporary thought. Berlin: Springer.

Fugali, E. (2012). Trendelenburg, Brentano und die Aristoteles-Renaissance in der deutschen Philosophie des 19. Jahrhunderts: die Frage nach dem Ursprung der Kategorien (s. 13-52). W: I. Tănăsescu (Red.). Franz Brentano's metaphysics and psychology. Bucharest: Zeta Books.

Hanuszkiewicz, W. (2011). Filozofia Hermanna Cohena w perspektywie sporu o jedność metody transcendentalnej. Warszawa: Wydawnictwo Instytutu Filozofii i Socjologii Polskiej Akademii Nauk.

Hartung, G. \& Köhnke, K. C. (Red.). (2006). Friedrich Adolf Trendelenburgs Wirkung. (=Eutiner Forschungen, 10). Eutin: Eutiner Landesbibliothek.

Köhnke, K. C. (1986). Entstebung und Aufstieg des Neukantianismus. Die deutsche Universitätsphilosopbie zwischen Idealismus und Positivismus. Frankfurt a.M.: Suhrkamp.

Kazimierczak, M. (1999). Wczesny neokantyzm. Poznań: Akademia Wychowania Fizycznego.

Langewand, A. (2002). Friedrich Adolf Trendelenburg. „Aristotelische” Pädagogik im 19. Jahrhundert (s. 79-100). W: K.-P. Horn (Red.). Pädagogik Unter den Linden. Von der Gründung der Berliner Universität im Jabre 1810 bis zum Ende des 20. Jabrbunderts. Stuttgart: Steiner. 
Löwith, K. (2001). Od Hegla do Nietzschego. Rewolucyjny przełom w myśli XIX wieku. (Przeł. S. Gromadzki). Warszawa: KR.

Noras, A. J. (2012). Historia neokantyzmu. Katowice: Wydawnictwo Uniwersytetu Śląskiego.

Orth, E. W. (1998). Metaphysische Implikationen der Intentionalität. Trendelenburg, Lotze, Brentano. Brentano Studien, 7, 15-30.

Orth, E. W. (2001). Trendelenburg und die Wissenschaft als Kulturfaktum (s. 49-61). W: W. Marx \& E. W. Orth (Red.) Hermann Cohen und die Erkenntnistheorie. Würzburg: Königshausen \& Neumann.

Petersen, P. (1913). Die Philosopbie Friedrich Adolf Trendelenburgs. Ein Beitrag zur Geschichte des Aristoteles im 19. Jabrbundert. Hamburg: Boysen.

Rotter, K. (1999). Kryzys i odrodzenie racjonalnej gramatyki. Wrocław: Oficyna Wydawnicza Politechniki Wrocławskiej.

Święcicka, K. (1976). Kantowskie a priori w filozofii niemieckiej lat sześćdziesiątych XIX w. Archiwum Historii Filozofii i Myśli Społecznej, 22, 267-294.

Święcicka, K. (1980). Kantowskie „a priori” w interpretacji Hermanna Cohena. Archiwum Historii Filozofii i Myśli Społecznej, 26, 161-189.

Wach, J. (1926). Die Typenlehre Trendelenburgs und ibr Einfluss auf Dilthey. Eine Philosopbieund Geistgeschichtliche Studie. Tübingen: Mohr. 
